\title{
Corporate Communication and Global Markets
}

\author{
Silvio M. Brondoni ${ }^{*}$
}

\begin{abstract}
The critical role played by intangible assets in corporate competitive development in global markets, has modified the nature of communication costs, and above all the costs of marketing communication.

Globalisation has produced deep changes in the function and role of the system of corporate information flows, which is expressed in the adoption of an integrated communication strategy. The gradual integration of global markets tends to eliminate static contexts and to replace them with dynamic and unstable environments, which generate huge changes even in the field of corporate communication, specifically with regard to the goals pursuable, the forms and instruments usable and obviously the audiences that can be reached.

Basically, integrated corporate communication: pursues the development of a culture of integrated communication; sustains the adoption by the organisation of behaviour and the practice of integrated communication; preserves the strong autonomy of the different operating units; and finally, it refers the concrete realisation of corporate network programmes to individual operating units.
\end{abstract}

Keywords: Corporate Communication; Integrated Corporate Communication; Network; Marketing Communication; Global Markets; Communication Costs; Communication Goals; Forms of Communication; Communication Tools

\section{Global Markets, Integrated Communication and Managerial Economics}

Globalisation has triggered the growing integration of competition spaces (marketspace management) ${ }^{1}$, but at the same time it has also generated the need for a systematic approach to corporate communication, due to the deep-rooted evolution of the very concept of enterprise, which must evolve on global markets ${ }^{2}$.

In recent years, it is true that numerous companies have substantially modified their view of corporate success (some time ago it was focused on the growth of manufacturing, sales and the workforce). They have also integrated the traditional quantitative parameters of results (basically founded on increased key product sales)

* Full Professor of Management, University of Milan-Bicocca (silvio.brondoni@unimib.it)

Brondoni Silvio M., Corporate Communication and Global Markets, Symphonya. Emerging Issues in Management (symphonya.unimib.it), n. 2, 2006, pp. 9-37 
with multi-dimensional competitive performance indicators, that link the indices of quantitative growth with the intangible dimensions of the brand and of the company as a whole ${ }^{3}$.

The critical role played by intangible assets in corporate competitive development in global markets, has modified the nature of communication costs, and above all the cost of communication for persuasive and/or informative tasks ${ }^{4}$.

In the fierce competition of the open markets on which global firms compete, communication costs exceed the nature of discretional cost (typical of closed markets where competition is weak and the tangible aspects of supply prevail). The sums spent on communication (for example, to sustain the brand image or awareness) would be calculated on each occasion at the management's 'discretion', on the basis of the economic availabilty for the period. On the other hand, in markets where competition is fierce, communication costs acquire the nature of causal cost (which is typical of open markets, where competition is fierce and intangible assets prevail), where communications costs are sustained to achieve specific, predefined objectives, in order to optimise management decisions and to monitor the discrepancies between the objectives set and the targets reached.

\section{Communication in Global Managerial Economics}

Global markets determine competitive space-time relations that specifically influence global corporate communication.

A first recognisable evolutionary factor is the loss of significance of the competitive reference of companies with a closed competitive landscape, which often coincides with specific physical or administrative boundaries (country, region, town, etc.). In fact, a to physical competition space now appears primitive and quite limited, with respect to a concept of competition in which specific geographical contexts are functionally expected to temporarily express peculiar partial competitive advantages (i.e. regarding research and development, manufacturing, marketing, sales, etc.), that must be coordinated on a vaster operating scale ${ }^{5}$.

What is more, globalisation and the links between markets have drastically reduced competitive action-reaction times (time-based competition). This phenomenon is being constantly strengthened by the growing importance of digital and ICT information flows, which make it possible to dialogue (online, i.e. without prior access to a medium, and in 'real time') with a multiplicity of 'points' (which are both the receivers and the sources of the communication, and therefore active subjects). This makes it possible to elaborate competitive intervention plans based on data and information deriving from constantly monitored actions ${ }^{6}$.

And finally, global markets determine deep changes in supply innovation policies, with evident repercussions on corporate communication. In this context, a first innovative dimension can be found in the simpler design of new products. This trend is linked to a reduction in the life span of the products themselves and a corresponding expansion of goods with very simple, and limited, usefulness (i.e. the so-called 'disposable' goods). What is more, in global markets, firms' supply policies must come to terms with faster imitation and dissemination of knowledge about new products, which are determined by the links between markets and even 
companies' global communication. As a whole, they tend to direct corporate strategy towards the domination of competitive phenomena (market-driven management ${ }^{7}$ ). Together, the design innovations cope with a substantial dematerialisation of the supply chain. As a result of this dematerialisation, a product tends to lose the qualities of correspondence with the 'normal' dimensions of its usefulness, being included in broader and more unstable assessment schemes, in whose definition intangible corporate and product assets play a central role ${ }^{8}$. As a result, corporate communication itself (in its various typical configurations) also plays a crucial role.

And finally, global managerial communication must come to terms with the changes still taking place in consumer behaviour, distribution structures and in the new structure of the media (digital and analogic). Globalisation has generated an exceptional physical mobility of the individual, and massive proletarianisation in the exploitation of mass media and the new digital media, which have drastically modified consumer behaviour. In the last 10-15 years, consumption models have changed rapidly as a result of the transformation taking place in international distribution structures, and specifically in the change from the fragmentation of sales outlets (in which distribution formulae based on microenterprise prevailed) to a more competitive and global approach to distribution systems ${ }^{9}$.

In the characteristics that distinguish a global corporation's communication, we must underline the role played by the source and receiver in today's mechanisms for the transmission and reception of information flows. Traditionally, on closed markets where there is no interaction, the figure of the receiver is a passive one, which can occasionally become active when certain feedback processes are activated. As a matter of fact, on open and strongly interconnected markets, this passive state cannot be generalised and the roles of source and receiver are no longer clearly distinct. The subjects exposed to communication (receivers) can in turn play an active role, even interacting in real time and even with multidirectional information flows, both with whoever transmits a given message (source) and with other subjects exposed to information flows ${ }^{10}$.

\section{Integrated Corporate Communication. Goals and Synergies; Costs and Benefits}

Globalisation has drastically modified the traditional parameters of: company size (where performance is less and less linked to the territory, depending rather on networking, outsourcing and delocalisation); space-time competitive relations; product design and sale (where competitors may even activate competitive cooperation relations, as is increasingly frequently in the motor industry); consumer models (emphasised by the decline in analogic media and above all television and television advertising, and the growing importance of the Internet and digital media); the crucial role of communication as a competitive tool, in economic systems with fewer protectionist components, distinguished by complex, open competitive spaces ${ }^{11}$.

The gradual integration of global markets does tend to eliminate static contexts and to replace them with dynamic and unstable environments, which generate huge 
changes even in the field of corporate communication, specifically with regard to the goals pursuable, the forms and instruments usable and obviously the publics that can be reached.

Where goals are concerned, in closed, static markets, corporate communication has traditionally been defined by distinguishing clearly between: persuasive and commercial communication, which revolves around communication flows designed specifically to achieve objectives linked to the company's core activities; informative and institutional communication, undertaken to achieve purely informative and not commercial goals, with communication flows that target opinion leaders and opinion makers who are not linked directly to company's core activities, but influence performance in various ways (stockholders, financial brokers, national and local public authorities, etc.). However, on global markets, the dynamism and complexity of competition do not make it possible to activate communication flows with partial aims, but rather encourage the exploitation of the synergies between communications with different aims (integrated communication) ${ }^{12}$.

The exploitation of close integration between the aims of communication, in order to coordinate the information flows directed at different types of receivers inside and outside the company (increasingly in organised networks, in multiple territories), emerges from the prevalence of short or very short-term schedules for commercial communication, and at the same time from the need to verify the effectiveness and efficiency of institutional communication. Moreover, in global markets, the traditional dualism of commercial and institutional communication is motivated by the transparency and permeability of the information that is typical of information.

Briefly, globalisation has produced deep changes in the function and role of the system of corporate information flows, which is expressed in the adoption of an integrated communication strategy.

In an integrated communication strategy, for example, the information flows cannot be considered primarily designed for the messages transmitted outside the company with a commercial content, but must interpret the overall strategic and environmental reality of a global organisation. In this sense, an integrated communication strategy must harmoniously combine its commercial objectives with its institutional and organisational ones, involving the various targets of the company's communications (general public, employees, co-makers). It must use the various tools available from the viewpoint of synergies of costs and benefits, in relation to the mix of reachable targets and usable tools. This is borne out by the fact that integrated communication favours the option of developing complex mixes in final/public relations, using heterogeneous tools to obtain synergetic combined effects.

What is more, in an integrated communication strategy, information flows reveal another distinctive phenomenon, i.e. overcoming the function of quantitative optimisation, based on the frequency and repetition of the message transmitted to a definite public-target, which is replaced by the integration between the quantitative and qualitative aspects of the flows that can be conveyed, in a vision of synergies of costs and expected effects from a targeted mix of transmitted messages. In concrete terms, the many communications tools usable in different circumstances persuade us to abandon the 'shockwave' communications policies of the messages transmitted (which can bring communication costs to an irreversible 'spiral effect' because they envisage a simplistic linear function between costs sustained and expected benefits), 
stimulating the search for solutions able to enhance the overall contribution of different instruments ${ }^{13}$.

In global companies, the coordination of the costs and benefits synergies of integrated communication is the results of precise motivations. First of all, the identity of a global organisation (network identity) ${ }^{14}$, with its many relevant publics, depends not only on the information flows put in place by formal communication processes, but also on the ways in which employees and co-makers interact with the organisation. These complex, inter-related communications underline the importance of strict checks on formal communications, planned to achieve defined goals, and of the messages transmitted by informal channels, which the company can monitor in a limited and therefore indirect way. The employees of complex global organisations are motivated to adopt positive, accountable and more efficient behaviour when they are involved in the corporate vision and mission, and they convey the identity of the organisation they belong to in the outside world.

\section{Integrated Corporate Communication. Analogic and Digital Communication}

Corporate communication is an intentional process that aims to transmit informative and/or symbolic messages that address several publics (internal, external, co-makers), in order to achieve objectives that may be commercial, organisational or institutional ${ }^{15}$. Corporate communication flows can be transmitted by communication channels and flows. The former identify preconstituted supports that allow a signal to be sent by the transmitter (source) to the receiver, and they therefore identify structures designed and set up specifically to enable communication to pass from the transmitter to the receiver. Communication flows, on the other hand, can be defined as organised communication systems that go from a transmitter to a receiver, normally along a channel. The purpose of the communication channel is to convey the flows of communication.

The distinction between channels and flows becomes very important in the management of information and of corporate communication. In global markets, to transmit information and communication flows, companies must invest in the creation (or identification) and maintenance of suitable channels to transmit the flows.

In global markets, Information \& Communications Technology (ICT) develops digital information and communication channels on one hand (with specific technologies that in time have produced the duplex telephone cable, optic fibres, and wireless connections), while it generates digital communications flows formed of packets that can contain data, sounds, images, films or various combinations of the same ${ }^{16}$.

Digitalisation drives development on global markets, where space is not only physical, but also virtual, made of relations, communication, information and transactions, highlighted and assisted by digital technologies, channels and flows. The virtual space enables various subjects to relate to each other (even simultaneously, in different locations) without a physical presence in a specific location.

In markets where competition is open, the digitalisation of flows and channels crosses the frontiers between communication and information: corporate 
communication is activated to spread a message, but its aim is above all to obtain returning information flows. The active interest of the receiver to 'send back' a communication determines the transformation from push communication to pull communication ${ }^{17}$. With push communication the company spreads a message, 'pushing' it in a channel to an audience that is not interested in the content of the message (passive interest). With a 'push' communication strategy, therefore, corporate communication passes through intermediate demands to reach the final receiver directly. In general push communication is activated in markets where the final receivers adopt passive behaviour, in other words they are not able to intervene in any way in communication between themselves and between them and the company-source ${ }^{18}$. With 'pull' communication, on the other hand, the communication flow starts 'from the bottom up' and it is requested by specific subjects. In other words, the subjects-targets try to acquire definitive information regarding specific areas of interest, revealing by this behaviour a specific motivation (active interest), which identifies an important distinctive characteristic of digital communication technologies. The response to digital communication makes it possible on one hand to measure the effectiveness of the flow activated, and on the other to acquire information about specific subjects targeted by the communication, defining their behaviour profile ${ }^{19}$.

In digital communication, one very important aspect is the possibility of checking out flows executed in an open cycle (feed-forward), in other words without waiting for the conclusion of an informative action, and the possibility of obtaining related feedback, after the dissemination of every communication flow, where the subjects involved, as source and target, are interdependent and do not influence each other with successive flows of information, which therefore remain in a closed cycle. With digital technologies, correct programming of the outgoing flow allows a suitable return flow, at no or very minimal cost.

Digital communication technologies have distinctive features that regard: the message dissemination speed, which links broadcasters and receivers in real time; the absence of space limitations to the 'circular' dissemination of messages, since the source and the target may be a considerable distance from each other, and because the roles of transmitter and receiver are not subject to flow hierarchy; economy, for the drastic reduction in the cost of transmitting messages, compared to the media and to analogic communications channels; flexibility, which characterises their amazing adaptability to the different needs of corporate communication and the availability of information in real time; multimedia, which makes it possible to manage different channels and/or communications media simultaneously, even updating communications plans immediately; and finally, interactiveness, i.e. the possibility of developing a two-way communication model that is profoundly different from the 'one-way' model (from a single source to many passive receivers) typical of analogic media and channels.

Digital technologies make it possible to manage enormous quantities of data and information, and as a result, they acquire and develop knowledge of the identifying characteristics of numerous interlocutors, without limitations of time or space (profiling).

Profiling identifies a further distinctive characteristic of digital communications. The profiling process is activated by creating a contact with a subject and associating 
an electronic 'reference' to it (IP, email, cookie, etc.). The profiling of individuals is developed with a series of electronic contacts, which classify the behaviour by introducing other information in addition to the planned stimuli. Profiling is an innovative characteristic of digital corporate communications, since knowledge of an individual's profile is completely impossible in analogic communications, and for this reason, companies must use behaviour profiling estimates, identifying the relevant targets and audiences to spread their messages.

The target thus represents a theoretical group of persons identified by a deductive process that originates from historical information about the audience's average behaviour, which still does not allow the individuals to be identified, and they remain indistinct, like 'black outlines'. A profile on the other hand, is the result of an inductive process, and each subject is contacted repeatedly, in depth and personally, so as to create mass communications that can be personalised (obviously impossible with analogic communications).

Digital communications are characterised by the measurability of results in relation to a wide range of elements: the large number of subjects reached (with assessments that are certain and not simply estimated on historical data, as is the case with analogic communications); the specific nature of the identifying characteristics of the targets contacted and to be contacted; response times, which are extremely rapid and not comparable with analogic media; and finally, the means of response obtainable, which can be cognitive (for example, to request additional information), affective (for example, to check the comprehension of a message) or behavioural (for example, to ascertain the level of consensus or degree of acquisition by particular subjects).

\section{Integrated Corporate Communication. Personal, Non-Personal and Telematic Communication Tools}

The system of corporate information flows can also be classified by the type of communication tools, which may be personal, non-personal and telematic.

Personal communication tools, in particular, presuppose the transmission of information through specific persons (sales force, opinion leaders, prescriptors ${ }^{20}$, etc.) and their distinctive characteristics identify:

- a direct process, with the simultaneous physical presence of the transmitting subject (source) and the receiver. What is more, the source and receiver have distinct, separate and non-overlapping roles;

- the personalisation of the contents of the information, which can be modified in relation to the particular receivers;

- the possibility of obtaining immediate, motivated responses from the receivers to a specific message transmitted by the source, with the consequent possibility of intervention (by the source and the recipient) with further analysis of the issues dealt with.

The sequential mechanisms of action and reaction and the personalisation of the contents transmitted, as a whole, underline the considerable effectiveness of personal communication, which does however have high contact costs, but little 
possibility of repeating the message (identifying the content transmitted), with the result that the use of personal communication tools is normally very limited and used to reach small and well defined segments of the public.

Non-personal communication tools, on the other hand, disregard physical, direct transmission and are characterised by:

- indirect message diffusion processes. The dissemination of information flows presupposes the use of suitable supports (media and vehicles to relate to the active (source) and passive (receivers) parties of the communication, which are not simultaneously present in time and space;

- a cost per person contactable that is well below that of personal communication, and therefore particularly suitable to develop mass and farreaching communication programmes;

- messages with content that cannot be personalised. On the other hand, messages may be repeated, in time and space, with absolute uniformity, or by varying specific elements but maintaining a substantial identity (i.e. with a high level of adaptability of the mass communication);

- the impossibility of performing immediate checks on the effectiveness of communications. The messages transmitted can only be checked some time after their transmission, by specific investigation of representative samples of the exposed audience;

- substantially one-way communication flows, whose effectiveness depends on the frequency and repetition of the same message, as well as on a suitable interval of time.

And finally, telematic tools ${ }^{21}$ develop information flows based on the transmission of messages in digital form, disseminated without limitations of space or time (therefore also regardless of the physical presence of the source and receiver), activated with the support of online computers (Internet, Intranet, Extranet). telematic tools have the following distinctive characteristics:

- communications are directed at well identified receivers, whose identities (and therefore their personal profiles) are guaranteed by personal system access codes;

- communication processes between transmitter and receiver can also be interactive and in real time, thanks to the information links between source and receivers. The retroactive information/response mechanisms therefore allow feed-forward and feedback, between transmitters and receivers, with subsequent classification and immediate analysis of the content of the messages transmitted;

- the cost per useful contact is very low, whereas the cost of setting up an information network is rather high, but this does make it possible to link the various receiving parties in a circuit. 


\section{Integrated Corporate Communication. External, Internal and Co-Makers Targets}

Another key aspect of the corporate communication of global corporations is the mix of numerous audiences. The priority receivers of communications by global corporations can typically be divided into targets: internal, external and co-makers.

Classifying corporate communication in relation to the many audiences-receivers allows us to observe that the design and development of an integrated system of information flows demand the preliminary identification of different targets that the firm intends to address, considering as targets any group of potential receivers, with specific identifying characteristics, that shows a current or potential interest, in defined space and time contexts.

In relation to the various targets identifiable it is possible to define specific profiles of public threats/opportunities, formed of identified individual or collective opinions that the company must come to terms with in dialectic terms through suitable tools, in order to achieve definite advantages or to limit the consequences of unfavourable events.

Internal information flows are intended to impact on employee behaviour, developing an effective link between different components of the company organisation.

Internal communications are transmitted by a system of channels ('media network') that support the company's organisational structure, and aim to limit the fortuitousness and spontaneity of the information flows, thus allowing the company organism to react correctly to the stimuli from inside and from the outside world. The internal 'media network' comprises numerous formal and informal channels. Formal channels include: meetings, AGMs, personal letters, conversations and interviews, internal communiqués, service orders and procedures, preparation, refresher and training programmes and permanent corporate publications (house organs).

Communications to targets outside the company (customers, suppliers, the financial world, public authorities, associations and lobbies, media, opinion makers and opinion leaders, etc.) aim to disseminate specific identifying corporate and/or brand connotations and to check the process that creates this identity, orienting it to corporate goals.

The dissemination of external, information flows aims primarily to establish a definite 'corporate/brand identity' and to this end it may draw on a wide range of personal, non-personal and telematic communication tools. With the various tools available, companies basically address the outside world with news, events and symbolic elements that together try to positively impact on the expected response from the outside world to the company itself, or to what it has to offer.

A given identity is defined by communication for commercial objectives, developed specifically to generate consensus around particular offers (products, product lines, stock lists, etc.), by communication for organisational tasks, activated to 'optimise' the functions of the organisational structure, and by communication for institutional goals whose objectives regard the development of the company as a whole.

The traditional division of the relevant publics into external and internal does not meet the communication needs of global companies. The internal/external 
dichotomy identifies a situation typical of companies that operate exclusively on local markets, where external information flows are associated almost entirely with advertising, while internal communication is basically limited to management of industrial relations and does not even consider the possibility of positive or negative visibility in the outside world.

The internal communication of global companies, on the other hand, offers numerous opportunities for contact with a wide range of external environments, and must therefore be managed so that it can play a precise role to enhance the corporate identity, and often to support marketing programmes. Particular segments of the public (belonging to the outside world, but with a significant influence on the company's core activities) have for some time paid considerable attention to the intrinsic and formal contents of communications, verifying their medium/long-term consistency and comparing them with the behaviour (of greater social, economicenvironmental, ethical and juridical significance) of 'corporate responsibility' and 'corporate social responsibility ${ }^{, 22}$, which global corporations adopt 'spontaneously' and 'without checks', i.e. outside programmed development lines expressed in communications with persuasive goals.

In other terms, global corporations show that they need to recognise another target public, which we could call 'co-makers' ${ }^{23}$, specifically identifying selected economic and social operators, both private and public, which whom a firm maintains (or intends to activate and develop) highly privileged relations, which influence the way it achieves its results for the period and are closely related to the achievement of its goals.

This audience of co-makers has its own specific characteristics. For example, it may include: franchised and 'quasi-franchised' retail structures (like petrol and fuel distribution networks); suppliers who are involved as partners in R\&D activities, both manufacturing and commercial; specific 'key-clients', particularly those belonging to highly competitive distribution channels; particular consultants, whose contribution is decisive to achieve specific managerial objectives; specific financial operators who interact with the company to define the timeframes and means of implementing development lines; and so on.

The co-makers therefore identify brackets of receivers of communications with specific identifying characteristics, which in some ways resemble internal audiences and in others the external public. In general, the main distinguishing features of a co-maker are summed up by the simultaneous presence of:

- the existence of formal agreements that establish preferential relations;

- continuous and very frequent relations (often based on personal contacts and regarding confidential issues);

- a high level of significance of individual relationships, which usually result in action destined to have a profound impact on the results for the period;

- a readiness to make a continuous contribution to the achievement of medium/long-term objectives, with a preferential or even exclusive involvement and sharing the corporate risks.

$\square$ One typical example of communication addressing co-makers regards the real estate sector, with specific reference to franchising agreements between the affiliating company and affiliated operating units. In particular 
'co-makership' information flows regard the management of 'business know-how', in other words the store of technical skills, knowledge and methodologies devised, perfected and experimented by the affiliating entity to market its products, with information flows that regard: the correct use of the trademark, the fields of application of the 'Visual Corporate Identity' (signs, shop-windows, furnishings), plans for the use of tried and tested selling, promotion and merchandising techniques, and finally, targeted communication regarding problems of commercial organisation, administrative consultancy and support in tax matters. In co-makership information flows connected to the management of 'business know-how' in real estate sales, the 'System Presentation Manual' is extremely important, focusing on: a description of how to use the trademark and a presentation of the product line; selling techniques and asset acquisition, inventories and storage methodologies; indications for price fixing; the creation of a computerised management control system; personnel policies; administrative, accounting, tax and insurance procedures. Co-makership information flows also envisage: an 'Architecture Manual', for uniform, correct furnishing of the point of sale; the 'Advertising Manual', containing the codes of practice and techniques for the launch campaign of the point of sale, and to promote specific company offers; meetings and seminars, with encounters between the affiliating company and the affiliated operating units to present the results achieved and the corporate strategies; and finally, 'continuous assistance and support', comprising editorial tools (house organs, bulletins, technical documentation, correspondence), telephone contacts, visits by personnel, training and refresher courses, and online assistance.

\section{Global Corporations and Integrated Communication Strategies}

The above considerations allow us to outline the various integrated communication strategies that could be adopted by global corporations. In this respect, corporate behaviour can be defined as:

- integrated product communication;

- integrated corporate communication;

- integrated communication with prevalence of external targets;

- integrated communication with prevalence of internal targets;

- integrated communication with prevalence of co-makers targets.

\subsection{Integrated Product Communication}

In global corporations, integrated product communication takes the form of the planning of numerous information flows that address external and internal targets and co-makers (see Figure 1), related to the implementation of a coordinated number of tools referred specifically to a given product.

The planned use of numerous tools, all designed to promote a specific company offer, tends to disregard a targeted synergetic orientation at overall company level, 
even while it must envisage long-term consistency, focusing rather on corporate behaviour that strives to achieve short and very short-term objectives.

Behaviour that disregards a communication strategy for the company as a whole (corporate identity) certainly cannot lead to a systematic integration of ends/information flows/targets - even for the various subsystems of the supply.

Figure 1: Integrated Product Communication

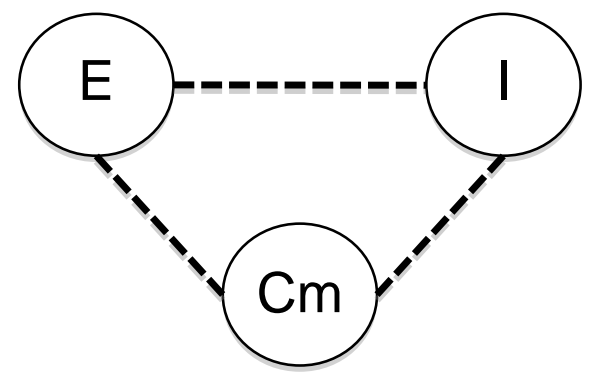

Where individual products are concerned, the various areas of communication (external, internal and co-makers) reveal extensive coordination. In fact (as we can see from the dotted line that links the various targets in Figure 1), the individual activities have close functional links, which in particular regard the choice - in terms of the optimal cost-benefit ratio - of the tools that can be used each time to achieve set objectives. However, the rationality of these choices refers primarily to an operational 'problem solving' approach, where the timeframe of the decisions is limited.

An integrated communication strategy, focused on individual offers and instrumental on the contingent need for commercial consensus, is generally reflected in global corporations with:

- an organisational structure dominated by the strong presence of brand managers and product managers, responsible for product profitability over vast geographical areas. This type of company usually operates with several product lines, in markets where competitive tension is high. Information flows addressing areas of communication other than the commercial area therefore become exceptions and consequently are rarely decision-making contexts that extend after the events that determine the demands of integrated communication;

- very accentuated and sudden competitive action, implemented by strongly 'communication oriented' competitors, with organisations that are accustomed to compete effectively with a combination of tools. For example, they organise combined advertising, publicity and 'consumer sales promotion' programmes that address external targets, simultaneously activating 'co-makership communication' programmes targeting the main commercial brokers. In conditions of competitive offensive for a given supply, a company exposed to competition is usually forced to react very rapidly and with 'multiple answers' (i.e. with simultaneous recourse to different tools), the consistency of which cannot be identified in terms of corporate strategy as a whole, nor in relation to principles of the soundness and space-time continuity of initiatives, but rather in the synergetic short/very 
short-term impact for the product that is subject to the competitive offensive, and in the degree of adherence of these exceptional actions to the communication plans put in place in conditions of normal competition (competitive stability).

\subsection{Integrated Corporate Communication}

Global corporations with structures dedicated to the implementation of external, internal and co-maker communication programmes reveal a different integrated communication strategy (typical examples of this can be found in groups of companies with strong 'Marketing', Human Resources', 'Research and Development' etc. managerial structures). These organisations tend to adopt an integrated communication strategy characterised by the planned interaction of the various areas (see Figure 2), which comes down to:

- a corporate strategy designed to assert a precise unitary identity (corporate identity) through the planning of institutional communication, to counterbalance the fragmentation of communication that is usually produced by the promotion of very specific offers (brand names). Typical examples of this can be found in the corporations (GE, Sony, Toshiba, Yamaha, etc.) whose supply is articulated in numerous dissimilar product classes on the demand side, albeit with the same company name;

- the need to coordinate different units of a single corporation that transmit continuative information flows with a high potential for intersection with different targets, particularly to avoid the dissemination of contradictory messages.

From the viewpoint of corporate planning, an integrated communication strategy is prompted by continuous internal information activities - usually stimulated by the activities of special Communication Committees, where the initiatives for the period are presented and discussed - which the various company functions and/or individual operating units activate before implementing specifically allocated communication programmes. This informative action aims to integrate the company's various communication initiatives while laying the foundations on which to build corporate programmes, i.e. those of interest to various functions/units, the cost of which is divided between their respective budgets, as in the case of cultural sponsorship programmes, or certain sporting sponsorships, because of their 'multiple effects' which can regard external and internal targets and co-makers at one and the same time.

Figure 2: Integrated Corporate Communication

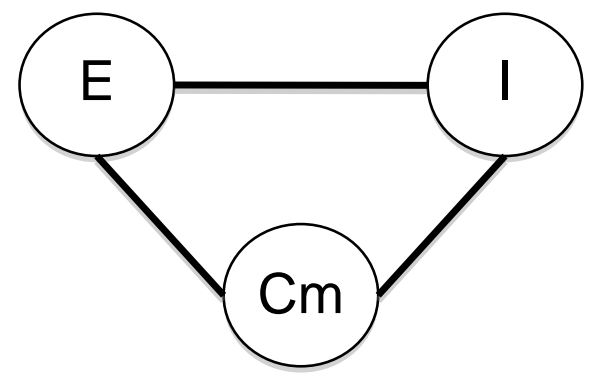


Integrated corporate communication therefore tends to develop thanks to the creation of strong planning, centralised in a specific company function that is responsible for controlling the communication system (typically a Communication Department or Communication Committee). This aims on one hand to analyse the motivation underlying individual projects (as well as preventing the emergence of any discrepancy), while on the other it sets out to institutionalise the overriding of the functional or decision-making environment of a particular operating unit to achieve broader corporate goals of awareness and/or image. This integration process therefore does not set out to eliminate the decision-making autonomy of the individual operating units in the network, which continue to be fully responsible for the decisions they take regarding the costs, methods and time necessary to implement the information flows they are responsible for.

The planned integration of the various units involved in the communication reveals numerous discrepancies compared to the corporate behaviour examined previously, which favours a product view. The latter focuses on the short/very short-term optimisation of communication programmes regarding a definitive product range, while the integration of the entities responsible for specific information flows is expressed on one hand by planned intervention, in other words with targeted, shared choices to exploit all the possible synergies, and on the other, it envisages the development of common action, planned around overall corporate programmes. These programmes are not directly linked to the objectives of individual activities, but generate common costs that are charged to the individual organisations on the basis of specific criteria ${ }^{24}$.

Basically, integrated corporate communication:

- pursues the development of a culture of integrated communication, with farreaching corporate and/or market goals, which transcend the focus on individual events and excessive emphasis on the instrumental viewpoint;

- sustains the adoption by the organisation of behaviour and the practice of integrated communication, obliging the managers of different corporate functions to confront each other formally, periodically and with regard to specific objectives and results, dealing with problems and tools that are not directly linked to their spheres of competence;

- preserves the strong autonomy of the different operating units. The latter, as a consequence, interact in depth on programmes with common development lines, while they conserve extensive decision-making discretion for areas of direct competence, for many aspects of which integration is therefore primarily formal $^{25}$;

- and finally, it refers the concrete realisation of corporate network programmes to individual operating units. The organs that coordinate information flows usually do not have dedicated internal and/or external personnel who are in a position to implement the initiatives that pursue general corporate goals. In concrete terms, integration between the different units is therefore limited to assessing corporate initiatives together, while their implementation is entrusted to the responsibility of a particular unit, chosen on the basis of available specific skills; the unit therefore functions as the authentic author of the success (or failure) of the actions taken to create the corporate identity ${ }^{26}$. 
Very briefly, a corporate integrated communication strategy may be expressed through a small number of initiatives, but these have excellent external visibility and a high level of internal involvement. They are developed taking as a reference the network as a whole, and they are planned in time and space with a strict consistency of goals, targets and tools. A corporate integrated communication strategy usually emerges in companies that are characterised by:

- extensive diversification and differentiation, with corporate behaviour dominated by marketing policies and the achievement of commercial objectives;

- a brand portfolio characterised, for given product classes, by the simultaneous presence of products with different positioning (brand; Bbrand; parallel brand $)^{27}$;

- frequent absence of a manufacturing function, which highlights activities to manage demand bubbles for products with very brief lifespans, but all linked by a single corporate brand ${ }^{28}$;

- communication policies with a new prevalence of external flows for commercial objectives (particularly advertising and sales promotion).

\subsection{Integrated Communication with Prevalence of External Targets}

In the case of integrated communication strategies with prevalence of external targets, integration policies presuppose that information flows to internal audiences and to co-makers are designed to be strictly functional to the priority needs of the external audiences (see Figure 3).

In order to integrate flows, the dominance of external communications does not translate only into the use of numerous different tools to address targets outside the company. More correctly, the dominance of external communications highlights a constant orientation by management to the planning and development of the overall communication system, characterised specifically by:

- a precise definition of the communication goals at corporate and product level, in order to harmonise the commercial product communication with the more complex goals of corporate identity;

- a strong focus of internal and co-maker information flows on efforts to increase the effectiveness and efficiency of external communications. The latter therefore reveal a clear and prevalent characterisation, both for the entity of the efforts directed specifically at external flows, and because external communications are the focal point of the entire communication system. For example, internal training activities tend to favour programmes that relate to problems expressed by specific external targets, or they set out to analyse issues that can profitably be referred to competitive dynamics. At the same time information that addresses co-makers can usefully be enhanced for competitive ends (for example, with the systematic enhancement of existing special relationships with certain consultants, designers, stylists, research centres, etc.); 
- a constant search for synergies - to be identified and quantified in advance for the various flows that can be transmitted to external targets in a given period of time. For example, information regarding new products during their launch (a regular occurrence in the automotive/motorcycle, casual clothing and other sectors), promoted with special offers and/or discounted to employees, to simplify and accelerate a competitive positioning in line with the objectives of other external communication tools;

- accentuated centralisation of responsibility for the planning and development of information flows, to avoid communicating content that is not fitting or even contradictory to primary external targets ${ }^{29}$. The planned elimination of a degree of decision-making autonomy is contemplated in Figure 3, specifically with the overlapping of the various domains (external, internal and co-makers), which aims to highlight the systematic design link between the various types of communication. From an operational viewpoint, significant examples can be found in assessments of the consistency and opportuneness of communication regarding negative or significant events (resignations and dismissals of personnel, crisis in the sector of activity, etc.), when the managers of the company activities in question (marketing, personnel, finance, etc.) have to share responsibility for the contents and actions of information flows under their remit on one hand, while on the other they must carry out a preventive evaluation of their consistency with regard to the relevant external targets (customers, commercial and financial brokers, public authorities, etc.).

The strategy to integrate information flows dominated by external communication therefore has certain distinctive features, which are:

- generalised and continuous integration, with the result that all product communication programmes intersect, and may condition but also favour initiatives of a corporate nature. The latter, in turn, are not classified only with regard to specific corporate communication programmes, in other words occasions on which the 'company name' prevails, but are expressed in a corporate logic in which the corporate dimension must be linked to the communication of the individual corporate products (brand names);

- the presence of dedicated personnel in the company, who are highly specialist in the integrated management of the various communication tools ${ }^{30}$. The combined use of a variety of tools does presuppose constant use of specialist skills that express familiarity with the use of the entire spectrum of tools that address external and internal targets and co-makers;

- a communication mindset - disseminated throughout the network and supported in the organisation - focused primarily on the outside world. Integrated communication is therefore expressed with a general predisposition to problem solving, founded on non-elementary knowledge of the various communication tools and problems;

- good visibility of the system of communication initiatives and the related possibility of estimating the costs met to develop the various activities specifically by direct competitors. The predominance of external communication directs company information flows towards tools and initiatives that are easy to identify, and actually simplify a 'reconstruction' of 
the structure of the communication system (as a whole, by country and by product at a given time), identifying and quantifying the main instrumental components of a specific plan. What is more, the visibility of the communication system makes it possible to determine synthetic indicators outlined by the consistency of barriers to communication on one hand - for determined sectors of supply and in specific competition times and spaces ${ }^{31}$ while on the other it constitutes an important stimulus to the adoption of imitative behaviour by less innovative companies that are more exposed to integrated communication programmes. The visibility of strategic tools and the ease with which they can be quantified are not a cause of concern for global corporations that successfully implement integrated communication programmes. In fact, the evaluation of the 'visible components' of a communication plan makes it impossible to identify the whole spectrum of usable tools (and also makes it difficult to estimate the related overall cost). Moreover, the cost of the tools used can be estimated only subsequently (after the activation of specific tools) and it is unlikely to make it possible to decipher the strategy of a particular communication plan, understanding the integrating mechanisms that determine the synergies between the various tools activated.

Figure 3: Integrated Communication with Prevalence of External Targets

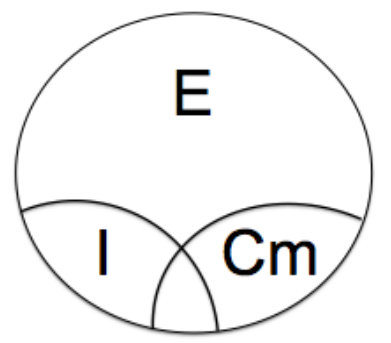

An integrated communication strategy with prevalence of external communication is very often linked to a company profile that reveals the presence of:

- market policies that are decidedly characterised by a 'marketing-oriented' approach which may, in the various circumstances, be expressed in active competitiveness on a large number of product markets (multimarket competitiveness), in a large number of product classes (multiproduct competitiveness), in the management of a large number of products in the same product class (multi-brand competitiveness), or in a combination of the above conditions (market-driven management) ${ }^{32}$;

- the precise identification of the minimal market share (i.e. the brand's survival threshold) for the various products in the company's brand portfolio. The fundamental 'key parameters' of this survival threshold can obviously be identified in demand potential and the intensity of competition;

- communication policies seen as a crucial competitive factor. The strategic role of communication demands extensive and systematic recourse to external specialists, paying specific attention to the best qualified and expert 
structures in their respective skill areas, in order to guarantee continuous, highly specialist consultancy ${ }^{33}$;

- and finally, corporate behaviour that considers timing as a specific factor of competitiveness (time-based competition). Where the communication system is target-focused (external, internal or to co-makers), time-based competition is expressed on one hand in the minimisation of the time associated to a certain competitive action-reaction cycle (time compression and time value) ${ }^{34}$. On the other hand it is also expressed in an 'advantage' in decision times due to the privileged access to primary and secondary sources of information (as in the case of collaboration with Research Centre, Scientific Institutes, etc.).

Briefly, integrated communication strategies based on the dominance of external information flows envisages on one hand that all initiatives are always coordinated, from a viewpoint of absolute, priority functionality to the various external stakeholders. On the other hand it presupposes strongly centralised management of information flows, which excludes consistent degrees of decision-making autonomy for the planning and implementation of the activities making up the corporate communication system.

\subsection{Integrated Communication with Prevalence of Internal Targets}

Integration strategies in which internal communication predominates are based on flows that address employees directly, and predominate over communication that addresses the outside world and co-makers (see Figure 4). When internal communication predominates, communication to the outside world and to comakers usually has very specific and limited goals, and its activation is therefore limited in time and space.

When internal flows dominate, communication to external targets and to co-makers may take the shape of occasional initiatives that are still functional to internal communication, albeit with varying degrees of freedom (indicated in Figure 4 by the absence of overlapping between the areas representing communication to the outside world and to co-makers).

Figure 4: Integrated Communication with Prevalence of Internal Targets

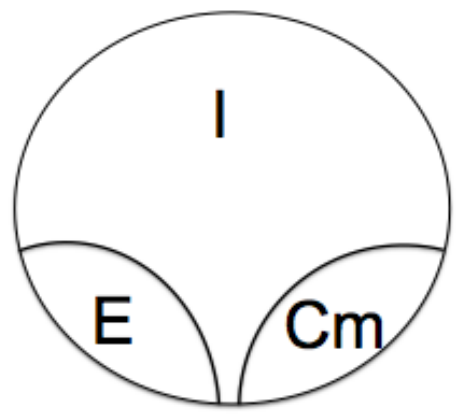




\begin{abstract}
$\square$ Typical examples of integrated communication by global corporations, with prevalence of internal communication, are the large corporations in the pharmaceutical sector. In these companies, promotional messages that address the outside world and specific commercial or financial brokers usually reveal entirely 'autonomous' content, and differ significantly from the messages sent (continuously, usually by telematic instruments) to select groups of operators (comakers) and prescriptors.
\end{abstract}

An integrated communication strategy that focuses on the internal components highlights the importance of links with employees in pursuing objectives related to the company's core activity. Internal communication generally tends to take precedence in global corporations with activities that have a high level of accountability (for example, companies that invest heavily in R\&D and companies with a high 'front line' ratio with the clientele), in other words organisations where routine tasks are delocalised and outsourced, or developed online or massively mechanised (like many over-the-counter operations in banks), while there is a high incidence of personnel interfaced with different targets. In other words, when interpersonal relations (between the various operating units of a network, or within a single operating unit) are crucially important for the company's development and specifically require constant information flows (updates of existing products, training to develop new products, training to increase the supply potential) to encourage employees to adopt responsibly active behaviour, but also to ensure widespread acceptance by personnel of the $\operatorname{credos}^{35}$ that are a fundamental part of the corporate culture ${ }^{36}$.

Integration strategies with prevalence of internal communication recognise that employees play a specific function as transmitters and therefore vehicles to propagate and qualify the company identity. This overturns the traditional view of the 'top-down' communication channel, which is considered passive and acritically receptive. As a consequence, internal information flows dominate in global corporations with highly professional and formalised activities, whose distinctive features reflect:

- the planning of short and medium-term objectives of information flows addressing employees. This accentuated qualification of intervention, in the most complex and ramified networks, demands explicit analysis and careful evaluation even of informal internal communication - particularly with regard to the contexts and manner in which it is expressed - in order to identify and possibly eliminate any impediment or obstacles to the effective, efficient transmission of formal internal communications;

- suitable procedures to determine the internal communication budget, which have their own methodologies, even if they are the fruit of more general criteria to establish the overall budget for corporate communication;

- the systematic use of procedures to check the effectiveness and efficiency of the flows transmitted. Rapid transmission and full comprehension of the contents (in 'top-bottom' flows, feedback and feed-forward) demand continuous monitoring of the internal 'media network', the levels of receptiveness of peripheral terminals, and the suitability of the retro-active 
mechanisms (absence of 'gate-keeper' and 'overturned funnel' effects ${ }^{37}$, favourable conditions to activate and collect returning information flows by 'peripheral' operating units, the absence of 'over-channelling' phenomena ${ }^{38}$, etc.).

In the context of a strategy to integrate the flow system, the predominance of internal communication takes on different configurations in the various competitive conditions in which companies operate, i.e.:

a. In markets where competition is weak, internal information flows tend to be bureaucratic, they also tend to be justified by the limited potential for product switching (typical examples can be found in activities protected by competitive conditions of economic scarcity, i.e. monopolies). In particular, the bureaucratic nature of internal communication is expressed by feedback that is propagated slowly and returns to top management in successive layers (see Figure 5); it also takes the form of a limited awareness of the need to relate with the areas of communication that address the outside world and comakers, with regard to which coordination tends to become a concrete requirement only in the presence of particularly serious problems;

Figure 5: Bureaucratic Internal Communications. Feedback/Feed-Forward

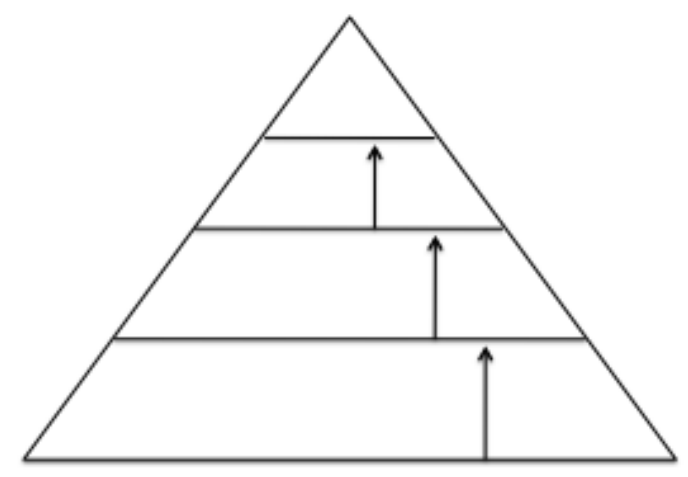

b. In highly competitive markets with a high rate of product switching, participative internal communication tends to emerge, which is highly personalised and interactive. Participative communication presupposes detailed knowledge of the individual entities that the various information flows address, with content designed to foster interaction between the entities exposed to the message, rather than to produce situations of passive reception. Participative internal communication also stimulates rapid retroactive processes (feedback/feed-forward) of different origins (see Figure 6), and in concrete terms it tends to limit the degree of freedom that can be exercised in interaction with the areas of communication addressing the outside world and co-makers. 
Figure 6: Participative Internal Communication. Feedback/Feed-Forward

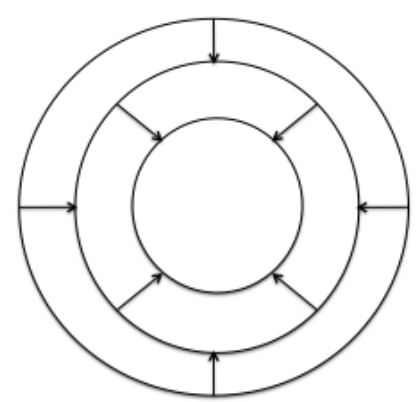

In conclusion, integrated communication strategies in which internal information flows take precedence, set out to assert defined profiles of responsibility like corporate identifying factors. To this end, it presuppose that all initiatives are designed and coordinated taking the internal public as their priority target, even though determinate degrees of freedom for the transmission of information flows to the outside world and to co-makers may subsist.

\subsection{Integrated Communication with Prevalence of Co-Makers}

And finally, the communication strategy with prevalence of co-makers reveals the importance of the information flows addressed to this particular type of partner, with whom the company has established a preferential relationship. Under this strategy, the messages transmitted inside and outside the organisation reveal fewer problems in pursuing the corporate goals and, as a result, the respective contents may be extremely independent, even if they must be closely subordinated to the need for communication expressed by co-makers (see Figure 7).

Figure 7: Integrated Communication with Prevalence of Co-Makers

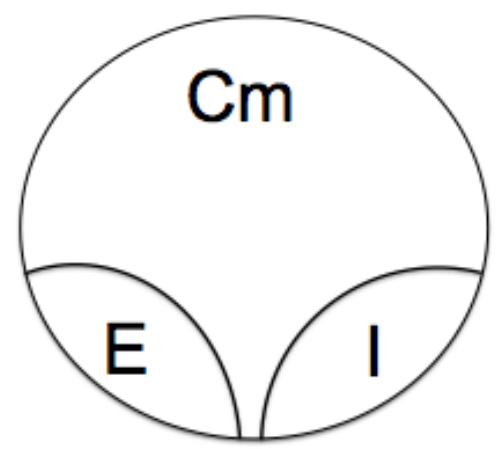

Integrated communication strategies, in which flows to co-makers dominate, are generally adopted for strategic corporate alliances, joint-ventures and high involvement corporate collaboration agreements ${ }^{39}$, or groups of companies ${ }^{40}$. In other words, in situations in which the goal of fostering interaction between partners becomes a priority, and a communication system in which the interfaces of 
the various operating units involved are an active part of communication designed to develop network links, becomes of crucial importance.

A communication system that aims to instil value into preferential partnership relations aims to make technology, culture and different corporate histories coexist, activating channels and tools that can help to improve knowledge of the network, which in any case must be grafted on to existing relationships of trust that have developed on an equal basis.

The lack of a balanced trusting relationship can prevent an integrated communication strategy developed from the viewpoint of 'co-makership' from being implemented. None of the parties involved could enter into lasting relationships, based on active participation and destined to spread responsibility for the areas of activity managed jointly.

Integrated communication strategies in which co-makers dominate have peculiar characteristics even in regard to the tools usable, which specifically envisage extensive use of interpersonal information flows, both written and verbal, often accompanied by non-personal tools with very specific and highly involving targets, such as local and remote telematic networks.

On the other hand, a communication strategy focused on the enhancement of comakership relations presupposes limited recourse to non-personal mass tools (and particularly to advertising carried by media with a vast audience spectrum). The external visibility of partnership relations is often pursued in order to exploit contingent market opportunities, but it rarely represents a focal element that qualifies the corporate identity, particularly for companies which (because of the vast size of their networks and the complexity of the corporate product range) are able to activate and successfully manage numerous long-term co-makership relationships. As a consequence, communication that addresses external targets, even if it has been designed to meet the priority needs of the co-makers can be established with numerous degrees of freedom, and this condition can also be extended to information flows that address the workforce.

Internal communication is certainly conditioned by a particular co-makership relationship only in the case of small operating companies with a limited and highly specialist range of products. In these conditions, the partnership relationship - which is usually unique - becomes so pervasive that it actually influences operations as a whole, and consequently also the flow of information to employees.

In situations where relations between partners is balanced, on the other hand, internal communication can take into consideration co-makership relations- in terms of contents and method of dissemination - and the different types of information flows are therefore created to encourage the process of cultural integration between employees and the operating units of the partners.

To sum up, a particular physiognomy emerges in strategies to integrate information flows in which dominate communication to co-makers, and it becomes a priority to assert the relationship of trust that exists between different operating units belonging to the same network, on an equal footing and in the long term. 


\section{Integrated Communication in Global Corporations}

The logic of integrated communication (global communication) is entirely in keeping with modern global managerial economics. In fact, in networks of companies, integrated communication must be able to adopt specific strategies and multiple tools to harmoniously combine objectives that are differentiated by geographical area and competitive intensity, in order to transmit information flows that are coordinated and synergetic in time and space, in relation to external and internal targets and co-makers.

In other words, corporate communication highlights the need to adopt decisionmaking and managerial models that reflect the complexity of the global networks, specifically revealing:

- recognition of the strategic nature of the communication, to develop the goals of awareness and image (corporate and product) in the various environmental and competitive contexts in which the firm operates;

- the adoption of the cost-benefit logic as a priority by management to decide the different forms of communication (personal, non-personal, telematic);

- the use of a planned multimedia approach, which on one hand highlights the practicality of the tools usable in the different circumstances in relation to the set objectives (maximised effectiveness and efficiency), while on the other it underlines the importance of including the company information flows addressing the various targets (external, internal and co-makers) in a system, to minimise the overall cost of communication globally and in the relevant market-spaces.

\section{Bibliography}

Arrigo Elisa, Corporate Responsibility in Scarcity Economy. The Olivetti Case, Symphonya. Emerging Issues in Management (symphonya.unimib.it), n. 1, 2003. http://dx.doi.org/10.4468/2003.1.10arrigo

Arrigo Elisa, Codignola Federica, Imprese globali e Cross Cultural Management, Silvio M. Brondoni (ed.), Cultura di network performance e dinamiche competitive, Giappichelli, Turin, 2006.

Bisio Luca, Corporate Responsibility and Local Corporate Governance in Europe, Symphonya. Emerging Issues in Management (symphonya.unimib.it), n. 1, 2003. http://dx.doi.org/10.4468/2003.1.09bisio

Brondoni Silvio M., Sponsorizzazione culturale e comunicazione aziendale, L'Impresa, n.4, 1987.

Brondoni Silvio M., Le strutture della comunicazione in Italia, L. Guatri (ed.), Trattato di economia delle aziende industriali, Milano Egea, 1988, pp. 486-488.

Brondoni Silvio M., La comunicazione integrata d'impresa nelle politiche di gruppo, AA. VV., Scritti in onore di Luigi Guatri, Ed. Bocconi Comunicazione, Milan, 1988.

Brondoni Silvio M., Comunicazione integrata e 'nuove sfide' competitive, R. Filippini, G. Pagliarani, G. Petroni (eds.), Progettare e gestire l'impresa innovativa, Etas Libri, Milan, 1992

Brondoni Silvio M., La comunicazione integrata nell'economia d'impresa, G. Lugli (ed.), Comunicazione e pubblicità. Analisi economica e dinamiche competitive, Egea, Milan, 1993. 
Brondoni Silvio M., Comunicazione, risorse invisibili e strategia competitiva d'impresa, Sinergie, $\mathrm{n}$. 43-44, 1997.

Brondoni Silvio M., Time Compression and Time Value as Competitive Strategy, in D. Caseby (ed.), Time and Management, ISIDA, Palermo, 2000.

Brondoni Silvio M., Patrimonio di marca e politica di comunicazione, Giappichelli, Turin, 2002.

Brondoni Silvio M., Ouverture de 'Market-Space Management', Symphonya. Emerging Issues in Management, (symphonya.unimib.it), n. 1, 2002.

http://dx.doi.org/10.4468/2002.1.01ouverture

Brondoni Silvio M., Ouverture de 'Corporate Responsibility \& Market-Space Competition', Symphonya. Emerging Issues in Management (symphonya.unimib.it), n. 1, 2003. http://dx.doi.org/10.4468/2003.1.01ouverture

Brondoni Silvio M., Network Culture, Performance \& Corporate Responsibility, Symphonya. Emerging Issues in Management (symphonya.unimib.it), n. 1, 2003 http://dx.doi.org/10.4468/2003.1.02brondoni

Brondoni Silvio M., Ouverture de 'Marketing Research and Global Markets', Symphonya. Emerging Issues in Management (symphonya.unimib.it), n. 2, 2003. http://dx.doi.org/10.4468/2003.2.01ouverture

Brondoni Silvio M., Risorse immateriali e concorrenza d'impresa, Silvio M. Brondoni (ed.), Il sistema delle risorse immateriali d'impresa: cultura d'impresa, sistema informativo e patrimonio di marca, Giappichelli, Turin, 2004.

Brondoni Silvio M., Market-Driven Management e neoprotezionismo, MARK UP, June 2005.

Brondoni Silvio M., Market-Driven Management: meglio e prima dei competitor, MARK UP, JulyAugust 2005.

Brondoni Silvio M., Network e cultura della concorrenza, in Silvio M. Brondoni (ed.), Cultura di network performance e dinamiche competitive, Giappichelli, Turin, 2006.

Brondoni Silvio M., Gnecchi Flavio, La comunicazione di Corporate Governance, Relazione al $18^{\circ}$ Convegno Annuale di Sinergie, L'evoluzione del capitalismo tra teoria e prassi: proprietà, governance e valore, Capua, 2006.

Contractor F.J., Lorange P. (eds.), Cooperative Strategies and Alliances, Pergamon, London, 2000.

Corniani Margherita, Agenzie di pubblicità e 'Brand Custodianship', Sinergie, May-December 1997.

Corniani Margherita, Sistema informativo aziendale e dinamiche competitive, Giappichelli, Turin, 2000.

Corniani Margherita, Demand Bubble Management, Symphonya. Emerging Issues in Management (symphonya.unimib.it), n. 1, 2002.

http://dx.doi.org/10.4468/2002.1.08corniani

Corniani Margherita, Segmentazione e aggregazione della domanda aziendale, Giappichelli Turin, 2004.

Day George S., Market-Driver Winners, Symphonya. Emerging Issues in Management (symphonya.unimib.it), n. 2, 2000-2001.

http://dx.doi.org/10.4468/2001.2.02day

Furlan Umberto, Corporate Culture and Global Competition. The Honda Philosophy, Symphonya. Emerging Issues in Management (symphonya.unimib.it), n. 2, 2002. http://dx.doi.org/10.4468/2002.2.05furlan

Garbelli Maria Emilia, Localizzazione produttiva e dinamiche competitive, Giappichelli, Turin, 2004. 
Garbelli Maria Emilia, Il sistema informativo nei network cooperativi di imprese, Silvio M. Brondoni (ed.), Il sistema delle risorse immateriali d'impresa:cultura d'impresa, sistema informativo e patrimonio di marca, Giappichelli, Turin, 2004.

Gatti Mauro, Cultura d'impresa,risorse immateriali e competitività, in Silvio M. Brondoni (ed.), Il sistema delle risorse immateriali d'impresa:cultura d'impresa, sistema informativo e patrimonio di marca, Giappichelli, Turin, 2004.

Gnecchi Flavio, Ricotti Paolo, Brand Portfolio Reengineering. The Gruppo Coin Case, Symphonya. Emerging Issues in Management (symphonya.unimib.it), n. 1, 2000-2001.

http://dx.doi.org/10.4468/2001.1.05gnecchi.ricotti

Gnecchi Flavio, Corniani Margherita, Demand Bubbles, Virtual Communities and Potential Demand, Symphonya. Emerging Issues in Management (symphonya.unimib.it), n. 2, 2003. http://dx.doi.org/10.4468/2003.2.04gnecchi.corniani

Gnecchi Flavio, Corniani Margherita, Le comunità virtuali nella misurazione del potenziale della bolla di domanda, in Silvio M. Brondoni (ed.), Il sistema delle risorse immateriali d'impresa:cultura d'impresa, sistema informativo e patrimonio di marca, Giappichelli, Turin, 2004.

Hitt Michael A., Ireland R. Duane, Hoskinsson Robert E., Strategic Management. Competitiveness and Globalization, South-Western College Publishing, Thomson, 2005.

Lambin Jean-Jacques, Market-Driven Management, McGraw-Hill, London, 2000.

Lambin Jean-Jacques, Brondoni Silvio M., Ouverture de 'Market-Driven Management', Symphonya. Emerging Issues in Management (symphonya.unimib.it), n. 2, 2000-2001. http://dx.doi.org/10.4468/2001.2.01ouverture

Martinelli Andrea Francesco, From Cornering to Virtual Cornering, Symphonya. Emerging Issues in Management (symphonya.unimib.it), n. 1, 2002.

http://dx.doi.org/10.4468/2002.1.07martinelli

Rancati Elisa, Risorse immateriali d'impresa e concorrenza basata sul tempo, Silvio M. Brondoni (ed.), Il sistema delle risorse immateriali d'impresa:cultura d'impresa, sistema informativo e patrimonio di marca, Giappichelli, Turin, 2004.

Rancati Elisa, Global Markets and Time-Based Competition, Symphonya. Emerging Issues in Management (symphonya.unimib.it), n. 2, 2005. http://dx.doi.org/10.4468/2005.2.05rancati

Reitano Antonella, Telematica concorrenza e comunicazione integrata d'impresa, Giappichelli, Turin, 2002.

Wind Jerry, Mahajan Vijay, Digital Marketing, Symphonya. Emerging Issues in Management (symphonya.unimib.it), n. 1, 2002. http://dx.doi.org/10.4468/2002.1.04wind.mahajan

Salvioni Daniela M., Il bilancio d'esercizio nella comunicazione integrata d'impresa, Giappichelli, Turin, 1992.

Salvioni Daniela M., Corporate Governance and Global Responsibility, Symphonya. Emerging Issues in Management (symphonya.unimib.it), n. 1, 2003.

http://dx.doi.org/10.4468/2003.1.05salvioni

\section{Notes}

1 Cf. Jean-Jacques Lambin, Silvio M. Brondoni, Ouverture de 'Market-Driven Management', Symphonya. Emerging Issues in Management (symphonya.unimib.it), no. 2, 2000-2001; George S. 
Day, Market-Driven Winners, Symphonya. Emerging Issues in Management (symphonya.unimib.it), no. 2, 2000-2001; Silvio M. Brondoni, Ouverture de 'Market-Space Management', Symphonya. Emerging Issues in Management (symphonya.unimib.it), no. 1, 2002; Silvio M. Brondoni, Ouverture de 'Corporate Responsibility and Market-Space Competition', Symphonya. Emerging Issues in Management (symphonya.unimib.it), n. 1, 2003.

2 Michael A. Hitt, R. Duane Ireland, Robert E. Hoskinsson, Strategic Management. Competitiveness and Globalization, South-Western College Publishing, Thomson, 2005.

${ }^{3}$ Silvio M. Brondoni, Risorse immateriali e concorrenza d'impresa, Silvio M. Brondoni (ed.), Il sistema delle risorse immateriali d'impresa: cultura d'impresa, sistema informativo e patrimonio di marca, Giappichelli, Turin, 2004.

${ }^{4}$ Cf. Silvio M. Brondoni, Comunicazione, risorse invisibili e strategia competitiva d'impresa, Sinergie, n. 43-44, 1997.

${ }^{5}$ Cf. Maria Emilia Garbelli, Localizzazione produttiva e dinamiche competitive, Giappichelli, Turin, 2004; Elisa Rancati, Global Markets and Time-Based Competition, Symphonya. Emerging Issues in Management (symphonya.unimib.it), n. 2, 2005.

${ }^{6}$ Cf. Margherita Corniani, Sistema informativo aziendale e dinamiche competitive, Giappichelli, Turin, 2000; Margherita Corniani, Demand Bubble Management, Symphonya. Emerging Issues in Management (symphonya.unimib.it), n. 1, 2002; Flavio Gnecchi, Margherita Corniani, Demand Bubbles, Virtual Communities and Market Potential, Symphonya. Emerging Issues in Management (symphonya.unimib.it), n. 2, 2003; Silvio M. Brondoni, Ouverture de 'Marketing Research and Global Markets', Symphonya. Emerging Issues in Management (symphonya.unimib.it), n. 2, 2003; Margherita Corniani, Segmentazione e aggregazione della domanda aziendale, Giappichelli, Turin, 2004.

${ }^{7}$ Cf. Silvio M. Brondoni, Market-Driven Management: prima e meglio dei concorrenti, MARK UP, July-August 2005; Silvio M. Brondoni, Market-Driven Management e neoprotezionismo, MARK UP, June 2005.

${ }^{8}$ Cf. Silvio M. Brondoni (ed.), Il sistema delle risorse immateriali d'impresa: cultura d'impresa, sistema informativo e patrimonio di marca, Giappichelli, Turin, 2004.

${ }^{9}$ Cf. Andrea Francesco Martinelli, From Cornering to Virtual Cornering, Symphonya. Emerging Issues in Management (symphonya.unimib.it), n. 1, 2002.

${ }^{10}$ In this regard, typical examples can be found in involvement in virtual communities and socalled quality circles, and also in participation in 'customer satisfaction' programmes, where interaction is actually planned and encouraged specifically with 'toll-free numbers' and interconnected ICT networks. Cf. Silvio M. Brondoni, Comunicazione integrata e 'nuove sfide' competitive, in R. Filippini, G. Pagliarani, G. Petroni (eds.), Progettare e gestire l'impresa innovativa, Etas Libri, Milan, 1992, p. 80 and following.

${ }^{11}$ Cf. Silvio M. Brondoni, Network e cultura della concorrenza, in Silvio M. Brondoni (ed.), Cultura di network performance e dinamiche competitive, Giappichelli, Turin, 2006.

${ }^{12}$ Cf. Silvio M. Brondoni, La comunicazione integrata d'impresa nelle politiche di gruppo, in AA. VV., Scritti in onore di Luigi Guatri, Ed. Bocconi Comunicazione, Milan, 1988; Antonella Reitano, Telematica concorrenza e comunicazione integrata d'impresa, Giappichelli, Turin, 2002.

${ }^{13}$ In global organisations, the search for synergies in integrated corporate communication has triggered a considerable improvement in the professional skills of company managers in the coordination of information flows. This has entailed confirmation of overall management of the various forms of communication (analogic and digital) on one hand, and of the various tools (personal, non-personal, ITC) that can be used by the company on the other. However, it has also stimulated integration and the finalisation of the content of the messages (commercial, corporate, organisational), to minimise the overall cost and to maximise the expected effectiveness of specific actions. Cf. Silvio M. Brondoni, La comunicazione integrata nell'economia d'impresa, in G. Lugli (ed.), Comunicazione e pubblicità. Analisi economica e dinamiche competitive, Egea, Milan, 1993. 
${ }^{14}$ Cf. Elisa Arrigo, Federica Codignola, Imprese globali e Cross Cultural Management, in Silvio M. Brondoni (ed.), Cultura di network performance e dinamiche competitive, Giappichelli, Turin, 2006.

${ }^{15}$ Cf. Silvio M. Brondoni, Patrimonio di marca e politica di comunicazione, Giappichelli, Turin, 2002 .

${ }^{16}$ Digitalisation transforms information and communications into bits (binary digits), i.e. binary numbers. In other words, a piece of information (data, text, pictures, sounds) is digitalised, translating and representing its original state (analogic) through a numeric combination of elements of the binary code ( $0-1$, yes-no, on-off). Digitalisation therefore makes it possible to transfer a signal that is extremely simplified, or potentially heterogeneous and with very complex content.

17 Cf. Silvio M. Brondoni, Flavio Gnecchi, La comunicazione di Corporate Governance, Relazione al $18^{\circ}$ Convegno Annuale di Sinergie, L'evoluzione del capitalismo tra teoria e prassi: proprietà, governance e valore, Capua, 2006.

${ }^{18}$ Cf. Silvio M.Brondoni, Ouverture de 'Marketing Research and Global Markets', Symphonya. Emerging Issues in Management (symphonya.unimib.it), n. 2, 2003.

19 Cf. Jerry Wind, Vijay Mahajan, Digital Marketing, Symphonya. Emerging Issues in Management (symphonya.unimib.it), no. 1, 2002.

${ }^{20}$ Cf. Jean-Jacques Lambin, Market-Driven Management, McMillan, London, 2000.

21 Cf. Antonella Reitano, Telematica concorrenza e comunicazione integrata d'impresa, Giappichelli, Turin, 2002.

${ }^{22}$ Cf. Silvio M. Brondoni, Network Culture, Performance \& Corporate Responsibility, Symphonya. Emerging Issues in Management (symphonya.unimib.it), n. 1, 2003; Daniela M. Salvioni, Corporate Governance and Corporate Responsibility, Symphonya. Emerging Issues in Management (symphonya.unimib.it), n. 1, 2003; Luca Bisio, Corporate Responsibility and Local Corporate Governance in Europe, Symphonya. Emerging Issues in Management (symphonya.unimib.it), n. 1, 2003; Elisa Arrigo, Corporate Responsibility in Scarcity Economy. The Olivetti Case, Symphonya. Emerging Issues in Management (symphonya.unimib.it), n. 1, 2003.

${ }^{23}$ For a common description of co-makers, see: Silvio M. Brondoni, Comunicazione integrata d'impresa e 'nuove sfide' competitive, in AA.VV., Progettare e gestire l'impresa innovativa, Etas Libri, Milan, 1992; Daniela M. Salvioni, Il bilancio d'esercizio nella comunicazione integrata d'impresa, Giappichelli, Turin, 1992.

${ }^{24}$ Typical or topical examples can be found in the sponsorship of large cultural or sporting events (like the Olympics and World/European Championships of very popular sports). Cf. Silvio M. Brondoni, Sponsorizzazione culturale e comunicazione aziendale, L'Impresa, n.4, 1987.

${ }^{25}$ In this regard, we should mention the choice of external professional partners who collaborate in the development of different types of communication (advertising agencies, sales promotion agencies, consultants for internal and co-maker communication, financial communication companies, etc.). With a corporate planned integration approach, the choice and remuneration of these professional structures falls under the direct responsibility of the various units to which the various communications tools can be attributed, while the bodies responsible for integrating the information flows (committees, working groups, etc.) usually stop at elaborating selection guidelines and general remuneration criteria.

${ }^{26}$ Checks on the effectiveness and efficiency of corporate initiatives are usually performed - on a collective basis - by the very organisms responsible for the selection and planning of issues, tools and events. These bodies also decide any corrective and supplementary action to be taken where partial results are shown to deviate significantly from planned objectives.

${ }^{27}$ Cf. Flavio Gnecchi, Paolo Ricotti, Brand Portfolio Reengineering, Symphonya. Emerging Issues in Management (symphonya.unimib.it), n. 1, 2000/2001; Silvio M. Brondoni, Marche 'commerciali', 'industriali' e pseudo-marche nell'evoluzione dei rapporti industria-distribuzione, Sinergie, June 1990. 
${ }^{28}$ Cf. Flavio Gnecchi, Margherita Corniani, Le comunità virtuali nella misurazione del potenziale della bolla di domanda, in Silvio M. Brondoni (ed.), Il sistema delle risorse immateriali d'impresa:cultura d'impresa, sistema informativo e patrimonio di marca, op. cit.; Maria Emilia Garbelli, Il sistema informativo nei network cooperativi di imprese, in Silvio M. Brondoni (ed.), Il sistema delle risorse immateriali d'impresa: cultura d'impresa, sistema informativo e patrimonio di marca, cit.

${ }^{29}$ In fact, if the Personnel Department of a given operating unit - on the basis of an independent decision - were to advertise situations vacant in a 'format' that is totally dissimilar to that adopted by the Personnel Department of other units of the same network, or even different from the formats used by the Marketing Departments for commercial communications, profoundly dissimilar messages might reach the outside world. The risk of different basic approaches tends to significantly boost the spread of corporate poles with decision-making autonomy regarding communications, inside the network.

30 'The changes taking place in the opportunities and communication needs of companies, have stimulated the rapid emergence and consolidation of new professional structures - alongside advertising agencies. They work exclusively on particular tools, with high standards of specialisation... Very briefly, the 'multimedia' option cannot be separated from a close finalisation of the available tools and therefore, inasmuch as it is concretely functional to the objectives to be achieved, it presupposes the precise coordination of the dedicated structures existing within the companies and external professional organisations.' See Silvio M. Brondoni, Le strutture della comunicazione in Italia, in L. Guatri (ed.), Trattato di economia delle aziende industriali, Milano Egea, 1988, pp. 486-488. On the same issue, see: Margherita Corniani, Agenzie di pubblicità e 'brand custodianship', Sinergie, May-December 1997.

${ }^{31}$ In this sense, the 'share of voice' (i.e. the ratio between corporate spending on advertising and advertising spending by each sector) must reflect a more complex instrumental multi-dimensional structure, overcoming the simple reference to advertising spending, which is only one element of an integrated communication strategy.

${ }^{32}$ The traditional 'marketing-oriented' approach, which can usually be linked to the success of large North American and, to a lesser extent, European corporations in the 70s and 80s, refers to competitive dimensions which in concrete terms presupposed a gradual expansion of specific brands and companies in numerous markets (international marketing management), according to a concept that was basically demand focused. In global markets on the other hand, a different competitive market-driven management' approach took hold, developed in the 1980s by large Japan-based corporations, which tends to assert a three-dimensional matrix (whose axes are respectively products, markets and brands). Market-driven management is expressed above all in the systematic exploitation of the results of basic and applied research (in particular, with an aggressive, innovative new product policy, that is free from the conditioning of existing production), and in the pursuit of an advance customer satisfaction logic, distinguished by a constant striving for incremental improvements to existing products and to manage demand bubbles.

${ }^{33}$ These external professional structures are also chosen for competitive ends, to prevent direct competitors from accessing the best skills (for example, by activating collaborative relationships with different consultancy structures and employing each of them in one or more communication projects). If it is to be competitive, the choice of an external professional structure envisages the application of a specific contract clause, defined as that of an 'exclusive relationship', on the basis of which a given consultancy organisation undertakes not to render its professional services to directly competitive companies-customers. This 'non-compete clause' is normally applied in contracts drawn up with advertising and sponsorship agencies, and it is not generally included in professional agreements with other partners (public relations, sales promotion, merchandising and product placement agencies).

34 The 'time compression' dimension concerns the value of the time factor where efficiency is concerned, related to the consumption of time. The 'time-value' dimension on the other hand regards the effectiveness of the use of the time factor. The 'time value' therefore expresses the enhancement of the use of time, within an action-reaction cycle, in which the 'consumption' of time is already 
considered suitably compressed. Cf. Elisa Rancati, Risorse immateriali d'impresa e concorrenza basata sul tempo, in Silvio M. Brondoni (ed.), Il sistema delle risorse immateriali d'impresa:cultura d'impresa, sistema informativo e patrimonio di marca, op. cit.; Silvio M. Brondoni, Time Compression and Time Value as Competitive Strategy, in D. Caseby (ed.), Time and Management, ISIDA, Palermo, 2000.

35 Cf. Umberto Furlan, Corporate Culture and Global Competition. The Honda Philosophy, Symphonya. Emerging Issues in Management (symphonya.unimib.it), n. 2, 2002.

${ }^{36}$ Cf. Mauro Gatti, Cultura d'impresa, risorse immateriali e competitività, in Silvio M. Brondoni (ed.), Il sistema delle risorse immateriali d'impresa: cultura d'impresa, sistema informativo e patrimonio di marca, cit.

${ }^{37}$ In the feedback and feed-forward processes of internal communication, the gate-keeping effect puts a block on returning information flows at given levels of the corporate organisation, and therefore creates a total interruption of the spread of knowledge chain. On the other hand, the 'overturned funnel' effect regards the possibility that - at the various stages of the 'return' flow - the information content progressively decreases in quality and quantity, thus resulting in the undue impoverishment and distortion of the message.

38 Phenomena of 'over-channelling' tend to emerge when there are strong stimuli to activate retroactive processes on one hand, whereas on the other, the peripheral terminals do not adopt suitable procedures (sequential, in successive layers, etc.) to select feedback/feed-forward information, thus causing congestion in certain channels of transmission (generally the most effective).

${ }^{39}$ Cf. F.J. Contractor, P. Lorange (eds.), Cooperative Strategies and Alliances, Pergamon, London, 2000.

${ }^{40}$ Cf. Silvio M. Brondoni, La comunicazione integrata d'impresa nelle politiche di gruppo, in A.V., Scritti in Onore di L. Guatri, cit. 